\title{
HISTORICAL ANALYSIS \\ OF THE MICROECONOMIC \\ PROCESSES ASSOCIATED WITH \\ THE DEVELOPMENT \\ OF THE INTERNET ${ }^{1}$
}

MASSIMILIANO NERI*

Resumen: El estallido de la burbuja de Internet señaló el final del boom económico americano de la segunda mitad de los años noventa del pasado siglo. Los múltiples errores empresariales cometidos durante ese período han reforzado la creencia de que el mercado libre conlleva imperfecciones que conducen inevitablemente al colapso. Este articulo desafía esa creencia analizando las intervenciones del gobierno americano desde el nacimiento de Internet (1968) hasta su comercialización y privatización (1995). Hemos demostrado que durante ese período, continuas dosis de intervención gubernamental han introducido distorsiones en el proceso de mercado. Entre ellas, las barreras a la formación de una estructura del conocimiento en el sector de Internet, crearon un terreno fértil para las malas inversiones realizadas durante el boom de Internet.

Palabras clave: Intervención pública, distorsión, fallo de mercado, Internet, estructura del conocimiento.

Abstract: The bursting of the Internet Bubble indicated the end of the American economic boom of the second half of the 1990s. The multiple entrepreneurial errors made during the euphoria of that period reinforced the belief that the free market is full of imperfections that lead inevitably to a collapse. This article challenges this belief by analyzing the American government's interventions from the birth of the internet (1968) to its commercialization and privatization (1995). We demonstrate that during this period continuous doses of government intervention introduced distortions

\footnotetext{
* Universidad Rey Juan Carlos. E-mail: maxneri@yahoo.com

${ }^{1}$ I'd like to thank for their precious feedback my Professor Jesus Huerta de Soto, Prof. Gabriel Calzada, Jose Ignacio del Castillo, Philipp Bagus, Prof. Carlo Lottieri, Carlo Zucchi, and Hayley Nelson. All errors being of course mine.
} 
in the market process; among them, the barriers to the formation of a knowledge structure in the Internet sector, created a fertile soil for the malinvetsments of the Internet boom.

Key words: Public intervention, distortion, market failure, Internet, knowledge structure.

JEL Classification: O33 (Technological Change: Choices and Consequences; Diffusion Processes).

If you can look into the seeds of time, and say which grain will grow and which will not, speak then unto me.

[William Shakespeare]

I. INTRODUCTION

The American economic boom of the second half of the 1990s is tightly bound to the surge the Internet. The boom was ended by a crisis that was initiated by the bursting of the Internet Bubble, anticipated by the stock market crisis signaled by the Nasdaq crash on April 2000.

For five years the ride over the new medium led many businessmen and economists to dream about a New Economy. However, the wind changed after the crash. The failure of the Internet entrepreneurs, reinforced a couple of beliefs that in the realm of economic science are a source of debate: first, that the free market, despite its undeniable benefits, is full of imperfections; second, that the excesses arising in an unrestrained market lead inevitably to a collapse.

This article challenges these beliefs. Ten years later, the errors committed by those entrepreneurs are quite clear. Still, the reasons why those errors occurred remain obscure, and at best are hidden behind the comfortable label of the market failures' paradigm. But today a growing number of economists have come to believe that this paradigm is unable to explain satisfactorily the Internet Bubble. On the contrary, by using the Austrian School paradigm, 
it is possible to identify the market processes that intervened in that period, leaving aside the restrictions inherited with the unrealistic hypothesis' of neoclassical microeconomics that fundamentally misconstrued economic reality.

Economic science cannot afford the luxury of dogmatism. For this reason we have analyzed critically the American's government interventions and the unintended consequences that these interventions have procured during the times of the development of the Internet. Indeed, by studying the distortions introduced into the free market by the government presence, interesting elements arise.

The moment that marks the explosion of the success of the Internet, the year 1995, coincides with the decision by the US Federal Government to commercialize its big public network. For this reason we propose to part our historical account in three periods:

a. Before the commercialization (1968-1995)

b. Commercialization and Privatization (1995)

c. Internet Bubble (1995-2000)

This article focuses on the first two periods and highlights a catalog of the government interventions that introduced distortion or even suffocated the microeconomic processes at work during the development of the Internet.

In the first part of the work we propose a historical account of the main events and government interventions during the history of the Internet. In the second part, an economic analysis of these interventions is performed following the theoretical paradigm of the Austrian School of Economics. 
II.

\section{THE HISTORY OF INTERNET}

\section{Before the commercialization}

a) ARPA First steps

(i) The Sputnik

In October 1957 the Soviet Unit launched the Sputnik satellite. This event was considered by the United States Government as a tremendous threat, because it demonstrated, during the tension of the Cold War, the Russians' apparent technologic superiority. The fact that Russia was able to reach the space was proof of its ability to launch intercontinental ballistic missiles.

A month later, the Russians launched the Sputnik II. While the first satellite had the size of a basketball, the second was nearly the size of a Volkswagen Bug${ }^{2}$. The panic spread all over the United States.

For the White House the need for a new entity that would fill the technological gap and re-establish American leadership in this field became a top priority. On January $7^{\text {th }}$, 1958, President Eisenhower announced the creation of the Advanced Research Project Agency (ARPA), a Pentagon's department, with the mission of financing academic research projects for the edgiest technologies that would allow to counter-attack a ballistic nuclear assault.

(ii) ARPA lavish financing

To ensure that the U.S. advanced its military research, the agency began to fund many projects, creating a strong relationship with the academic research field. This soon attracted the good will of many scientists that had visionary ideas, but failed to find funds

2 K. Hafner, M. Lyon, Where the wizards stay up late, Touchstone, 1996, New York. 
in the private sector ${ }^{3}$. Many of them were engaged in exploring the interaction between humans and computers; others began to envision the idea of a computer network ${ }^{4}$.

The spectrum of the funded activities was quite large. It is quite common to waste public money when the goal of a project comes not from some revealed need in the society but from a decision centrally mandated by a program committee. This principle applied to ARPA with no exception. In fact even the strongest supporters of ARPA's success in pioneering the first steps of Internet recognize that the agency had a sort of lavish attitude in funding any project that was in line with its mission ${ }^{5}$.

\section{(iii) ARPANET}

In the 1960s ARPA conceived the construction of a special purpose computer network. The project grew out of two concerns: a) the high cost of computing, and b) the potential vulnerability of the U.S. communications network to nuclear attack ${ }^{6}$.

3 In the next section we will see one of the important reasons why private business, at that time, didn't have the incentive to invest in projects in this area.

4 In 1962, J.C.R. Licklider «belonged to a small group of computer scientist who believed that people could be much more effective it they had at their fingertips a computer system with good databases». «A computer should be something anyone could interact with directly, eliminating computer operators as the middlemen in solving their problems». He was an «ardent evangelist of bringing the power of the computer right to everyone's fingertips». Harfner \& Lyon, Ibid. Other names of great scientists that contributed to the development of the first computer network are Bob Taylor, Larry Roberts (considered the father of the ARPANET), Paul Baran (RAND), Donald Davies (a British computer scientist who independently invented «packet-switching»), Frank Heart (manager of BBN's project team). For an account of the work of these and other great men, see Harfner \& Lyon, Ibid.

${ }^{5}$ When Taylor became director of IPTO in 1966, «the only difference, which turned out to be crucial, was that ARPA — now headed by Charles Herzfeld [...] — was even faster and looser with its money than it had been during Ruina's tenure. A joke circulated among its program directors: Come up with a good idea for a research program and it will take you about thirty minutes to get the funding». Harfner \& Lyon, Ibid., p. 41

6 Michael A. Geist, The Reality of Bytes: Regulating Economic Activity in the Age of the Internet, (http:/ / web.archive.org/web/20020319043328/http:/ / www.law.washington. edu/wlr/GEIST.HTM) 
ARPA maintained that there was a significant shortage of costly computer equipment, because researchers working on similar issues at different institutions were all requesting their own computers. The director of ARPA's Information Processing Techniques Office (IPTO) felt that the duplication of computer systems was costly and inefficient and suggested to develop electronic linkages between computers to enable researchers to pool their efforts and make a more efficient use of precious computer resources ${ }^{7}$. The idea was to share computing resources and data over a network. Regrettably, the traditional circuitswitched telephone system was not sufficiently reliable for this purpose. It was at this time that ARPA turned its attention to packet switching networks.

At that time, three scientific research groups worked on packet switching networks (unaware of each other's findings) ${ }^{8}$ : one from MIT, one from the British NPL and one from RAND Corporation $^{9}$. RAND researchers were concerned by the vulnerability of the national communications network, because the country's ability to launch a counter strike against an attack depended upon the operational survival of the national longdistance networks ${ }^{10}$. It was working on this project that they presented a proposal for packet switching voice communications.

In August 1968, after ARPA had refined the overall structure and specifications for the ARPANET, a Request For Quotation ${ }^{11}$ was released for the development of the packet switches (called Interface Message Processors -IMP's). The tender was won a month later by Bolt Beranek and Newman (BBN) a consulting

7 Geist, Ibid.

8 Packet switching breaks single messages into a series of smaller blocks or packets. When a message is sent, the computer create a series of packets, each containing a final address, which will be transported using different routes and then reassembled at their final destination. Geist, Ibid.

9 Barry M. Leiner, Vinton G. Cerf, David D. Clark, Robert E. Kahn, Leonard Kleinrock, Daniel C. Lynch, Jon Postel, Larry G. Roberts, Stephen Wolff, A Brief History of the Internet, (http:/ / www.isoc.org/internet/ history/brief.shtml)

10 Geist, Ibid.

11 Request For Quotation (RFQ). The original ARPA-RFQ document is available at: http://www.cs.utexas.edu/users/chris/DIGITAL_ARCHIVE/ARPANET/ RFQ-ARPA-IMP.pdf 
firm from Cambridge, Massachusetts. Honeywell provided the computers and AT\&T the telephone cables.

The first IMP and host computer was installed at UCLA in September 1969. The Stanford Research Institute (SRI) provided a second node that became operative a month later, and two more nodes were added at UC Santa Barbara and University of Utah. Thus, by the end of 1969 , four computer centers were connected together into the initial ARPANET. The network grew at a pace of roughly one new node per month in the early 1970s, with additional IMPs installed at institutions on both coasts including MIT, Harvard, and Carnegie Mellon ${ }^{12}$.

(iv) Why the ARPANET was built

As we have seen, the rationale for such project was based on the converging needs of two organizations. On the one hand, ARPA, motivated by cost cutting reasons in advanced research, conceived the network as a facility to connect the «inhomogeneous» computer systems of its various contractors ${ }^{13}$. As the RFQ said, this network was devised to «make these advanced research computer systems available to users outside their own design circle» ${ }^{14}$. On the other hand, the security concerns of the RAND Corporation called for the establishment of a reliable national communication network for military purposes ${ }^{15}$. It was on this ground that this first military network, intended to connect military personnel and defense

\footnotetext{
12 Geist, Ibid.

13 ARPA RFQ, supra note 10.

14 «Each system is oriented to the specialized research of the contractor and after connection to the network, will continue to operate primarily as a stands-alone system for that contractor's use. Each contractor will make some part of his facility frequently available to the network; however, network operation must not depend upon any single contractor's machine». ARPA-RFQ, supra note 10.

15 Circuit switching reserved a physical line between the two sides of a communication for the entire duration of the telephone call. Alternate paths might not be available and any of the devices that supported the communication could have been destroyed in a war, breaking the connection.
} 
contractors $^{16}$, connected the universities that cooperated with the major research projects controlled by ARPA ${ }^{17}$.

\section{b) Economic Incentives in the American telecommunication sector during the Sixties}

Before continuing with the history of the Internet, it is useful to take a step back in order to analyze why private business in the 1960 s did not support the idea of a computer network over telephone lines.

The ARPANET was funded by the federal government at a time when AT\&T had been asked by RAND to collaborate in developing a packet switching network that would solve the security concern about the fragility of their circuit switching telephone network. AT\&T felt packet switching was a preposterous theory for a network system. They thought that the government simply did not understand the telephone system, therefore they refused to cooperate in the development of a packet switched network for the government. As a result, the military sector decided to build the network itself to keep the program alive ${ }^{18}$.

(i) The Bell system: a Government's regulated Monopoly

In the 1960s, the American telephone system operated as a monopoly regulated by Federal and State Governments, in

16 Steve Bickerstaff, «Shackles on the Giant: How the Federal Government Created Microsoft, Personal Computers, and the Internet», Texas Law Review, Volume 78, Number 1, November 1999.

17 Although electronic mail was not in the original plans, ARPANET researches were distributed across several time zone, and soon grew tired of attempting to catch each other on the telephone to discuss their research. By 1973, they had implemented distributed electronic mail across the network so that they could easily communicate across time zones. E-mail quickly became the most popular service on the ARPANET.

18 Bickerstaff, Ibid, p. 39. 
compliance with a legal framework that was almost fifty years old $^{19}$. Prof. Bickerstaff's described quite eloquently the state of American telephone system in those times:

At the time, the national telephone network operated as a monopoly regulated jointly by the FCC and the regulatory commissions of the various states. Local telephone systems were owned and operated by twenty-two Bell Operating Companies or by various independent telephone companies. Each local company operated as a monopoly provider of telephone service within its local calling area. AT\&T, through its «Long Lines Department,» was the monopoly source of long distance transmission capabilities connecting these local calling areas. In addition, AT\&T owned all or most of each of the local BOCs, along with Western Electric (its manufacturing subsidiary) and Bell Laboratories (its research and development arm). The combination of AT\&T, the local BOCs, and the associated subsidiaries was known as the «Bell System».

Altogether, the Bell System and the independent telephone companies constituted not only a nationwide telephone network, but a unified, comprehensive marketing structure through which residential and business consumers obtained their telephone instruments, household wiring, equipment and wiring maintenance, operator services, directory information services, local calling capability, long distance services, and other telecommunication needs. For each consumer there was one, and only one, telephone company ${ }^{20}$.

19 The system was firstly created with the Kingsbury Commitment of 1913 (between Bell and the United States Department of Justice), which eventually achieved stability with the Federal Communication Commission Act of 1934. See R. Noll, B. Owen, «Anticompetitive Uses of regulation: United States vs. AT\&T (1982)», in J. Kwoka and L. White, The Antitrust Revolution (http://www3.oup-usa.org/sc/ 0195161181/pdf/0673468801_12.pdf), p. 331.

20 Bickerstaff, p. 7. 
(ii) Inadequacy of the Government monopoly to innovate

As Prof. Armentano points out, the Federal regulations on the telephone system promoted the absence of competition, inhibited innovation and favored AT\&T's self-protective lobbying behavior.

Government regulation had been the primary obstacle to a truly open-market competitive process in telecommunications. The Federal Comunications Commission has long restricted entry into long distance telecommunications and had regulated the rates of the monopoly supplier, AT\&T. Entry into local telephone markets had been legally restricted by state governments, and phone service and rates had been regulated by public utility authorities. AT\&T had a long history of advocating government regulation and monopoly in telecommunications and of opposing attempts to increase competition by decreasing government regulations ${ }^{21}$.

Prof. Rothbard emphasized as well the anticompetitive situation created by this government-controlled monopoly.

When the FCC confers a monopoly on AT\&T, there are numerous other firms and businessmen, small and large, who are injured and excluded from the privileges. The conferring of a monopoly of communications on AT\&T by the FCC, for example, for a long while kept the now rapidly growing data communications industry stagnating in infancy; it was only an FCC decision to allow competition that enabled the industry to grow by leaps and bounds. Privilege implies exclusion, so there will always be a host of businesses and businessmen, large and small, who will have a solid economic interest in ending State control over their industry ${ }^{22}$.

Indeed, as for any government-protected monopoly, AT\&T's attitude toward innovation was somehow short sighted. Even

21 D. Armentano, Antitrust: The Case for Repeal, Ludwig von Mises Institute, 1999 , p. 28.

22 M. Rothbard, For a New Liberty, Collier Books, London, 1973, p. 318. 
Hafner \& Lyon, which historical account of the period is considered without exceptions one of the most trustable, describe without reserves AT\&T's conservatism and lack of innovation drive:

The company was tenacious about its strong hold on both telephone services and the equipment that made such services possible. Attachment of foreign (non-Bell) equipment to Bell lines was forbidden on the grounds that foreign devices could damage the entire telephone system. There was almost no way to bring radical new technology into the Bell System to coexist with the old. [...] Not surprisingly, then, in the early 1960s, when ARPA began to explore an entirely new way of transmitting information, AT\&T wanted no part of $\mathrm{it}^{23}$.

Although in 1966 the physical network remained almost wholly designed for circuit switching of analog voice communications, the FCC, and many other observers, already felt that the Bell System might soon become a source of computer services for the general public ${ }^{24}$. However, a legal restriction on market entry and competition (known as «1956 consent decree») prevented AT\&T from competing in non regulated markets, such as data processing 25 .

In the 1960s the FCC was concerned that data processing services by the telephone company would compete with services sold by computer firms, while these same firms would be dependent on the telephone company for reasonably priced communication facilities and services. On the other hand, these

${ }^{23}$ Hafner K., Lyon M., Where the wizards stay up late, Touchstone, 1996, New York, p. 52

${ }^{24}$ Bickerstaff, p. 12.

25 Armentano, p. 26. In the 1956 consent decree, the Bell System had agreed that, in return for being able to retain ownership of Western Electric, the Bell System would limit itself to providing only «regulated common carrier services». The consent decree actually provided that: «The defendant AT\&T is enjoined and restrained from engaging ... in any business other than the furnishing of common carrier communications services; provided, however, that this Section V shall not apply to ... (g) businesses or services incidental to the furnishing by AT\&T . . . of common carrier communications services.» Bickerstaff, p. 15. 
non-regulated computer firms were increasingly able to transmit messages between different customers, an activity that the FCC viewed as limited to the communications common carrier ${ }^{26}$.

The inquiry conducted by the FCC in 1971, known as Computer $I$, decided not to regulate the computer industry and confirmed the 1956 consent decree. In other words, AT\&T was not allowed to provide data processing services over its network, while computer firms were allowed to do it ${ }^{27}$.

We have here an example of how the non-abolition of an existing antitrust restriction influences the development of the market. Moreover, this is the first obstacle encountered by those who support the view that the private industry failed to provide the groundwork for investing in the creation of a computer network. This is a crucial point indeed. When scientists were ready to explore the feasibility of a computer network over telephone lines, the experts acknowledged that the inadequacy of the AT\&T's outdated analog network represented the major barrier $^{28}$. Not driven by the competition, telephone companies lacked adequate incentives to make the digitalization of the local network a top priority. One reason for this lack of incentive can be identified in the Computer I prohibition for the Bell System to use its telephone network to provide computer services ${ }^{29}$. With the Bell System prevented from furnishing any service that crossed the border of the regulated communications realm, we move now to see whether private computer companies or noncommunication firms had the chance to fill this gap.

\footnotetext{
26 Bickerstaff, p. 12-13.

27 The FCC found that the data processing market was essentially competitive and observed that regulation was only appropriate where a «natural monopoly» exists. Otherwise, according to the FCC, allowance should be made for «the maximum possible latitude for individual initiative.» The Commission found no natural or economic barriers to entry in the data processing market and no indication of any threat of monopolization. Therefore, the Commission concluded that there was no public interest in requiring regulation of data processing and that, in fact, there was substantial public benefit in leaving the data processing market unregulated. Bickerstaff, p. 14.

${ }^{28}$ Bickerstaff, p. 26.

29 Bickerstaff, p. 27.
} 


\section{(iii) Incentives toward innovation in the private sector}

The unregulated non-telephone companies that wanted to venture into exploring the computer network communications found in their path two insurmountable obstacles, that eliminated every incentive for the entrepreneurial action. First, any company that was willing to offer computer and communication services among subscribers faced the risk of becoming subject to future regulation ${ }^{30,31}$. Second, the economical and legal terms at which they would had to lease transmission lines from the telephone companies were everything but acceptable and affordable ${ }^{32}$.

30 Bickerstaff, p. 19.

${ }^{31}$ The FCC had left data processing unregulated but uncertainty about what might constitute a regulated hybrid computer-communications service left many businesses reluctant to initiate such a venture, fearing that such action would subject them to federal regulation. Bickerstaff, p.19.

32 Bickerstaff reports a detailed list for these legal and economical barriers:

1. Bell System tariffs prohibited the attachment of terminal equipment to the telephone network without the use of a protective interface acquired from the telephone company;

2. Broadband, high-speed digital transmission facilities continued to be largely unavailable as part of the public switched network, and dial communications over analog local lines were too slow and unreliable;

3. When available, dedicated lines capable of high speed digital transmission of data required costly special installation, were tariffed at rates significantly above ordinary telephone lines, and varied in cost by the distance the data was transmitted;

4. Telephone company tariffs restricted the sharing and prohibited the resale of the use of telephone company lines, thereby further handicapping a subscriber's efforts at cost reduction;

5. Telephone company tariffs prohibited the interconnection of dedicated lines or the transmission facilities of other carriers to a telephone company's switched network;

6. Delays in the provision and maintenance of needed data circuits or other equipment by telephone companies were common;

7. Telephone company tariffs prohibited the use of telephone company facilities by a subscriber to transmit communications between two persons, thereby assuring that the telephone company could question any use of telephone company lines by a subscriber planning to transmit messages among computer users;

8. Intrastate tariffs or restrictions imposed by state and local government on intrastate and local calling and on interconnection to the local exchange network continued even after interstate restrictions were relaxed. 
At a time when science was ready to take the first step towards the Internet, the federally regulated monopoly of communications was prohibited entrance to the new market and the private computer sector was discouraged in doing so. The government had blocked the development of the network by the private sector into a net of prohibitions, an unsolvable deadlock.

Given this, would it be reasonable to wonder why only the government was able to put in motion a project like the ARPANET and why only further public interventions and funding pushed ahead the venture without the emergence of any qualified private player?

\section{(iv) AT\&T 1982 Antitrust Divesture}

As the computer industry evolved and provided machines increasingly efficient, the regulatory and financial costs for providing services over a network soon became the most costly budget item. It was then that the FCC, once again, turned upsidedown the industry with a historical decision, solicited, on one hand, by the grand advances made in the meantime by the microprocessor industry and, on the other hand by pressure from AT\&T, who meanwhile had understood the great disadvantage caused by the prolonging of the old 1956 consent decree. The AT\&T regulatory soap opera ended with a new antitrust divesture that Armentano defined as «arguably the most significant employment of antitrust regulation in the history of antitrust enforcement» (United States v. AT\&T, 1981, 1982) ${ }^{33}$. The only positive aspect, from the point of view of this work, was the end of the 1956 consent decree.

By the time of divestiture on January 1, 1984, AT\&T was authorized to enter the computer and networking market. However, much had changed since 1970. Instead of being the primary, if not the sole, carrier capable of efficiently mixing communications and computers, AT\&T in 1984 found itself to be

33 Armentano, p. 26. 
just one (albeit the largest) of many long distance carriers, some of which had focused in previous years on providing broadband alternatives for data transmission by large companies ${ }^{34}$. Moreover, AT\&T no longer had control of the monopoly of local network whose access had to be obtained to provide network computers and long distance services. Perhaps even more importantly, the once-anticipated opportunity for a computer utility using centralized computer facilities to offer computer services to the general public seemed to have been overwhelmed by the revolution in personal computers ${ }^{35}$.

\section{c) The National Science Foundation}

In the 80s the National Science Foundation (NSF), an independent federal agency, gradually took the reigns from the ARPA and became the central funding and decision-making agency for the ARPANET, although they jointly continued its expansion $^{36}$.

\section{(i) CSNET}

At the beginning of the 80s the NSF had ventured in starting up the CSNET, a network to connect the country's computer science departments. CSNET was an attempt to stop the exodus of computing talent from academia to industry ${ }^{37}$ by using government

\footnotetext{
34 Bickerstaff, p. 36.

35 Bickerstaff, p. 36.

36 Brett Frischmann, Privatization and Commercialization of the Internet Infrastructure: Rethinking Market Intervention into Government and Government Intervention into the Market, 2 COLUM. SCI. \& TECH. L. REV. 1 (June 8, 2001) http://www.stlr.org/ cite.cgi? volume=2\&article=1, p. 12

37 Scientists were attracted by the opportunities offered by the successful computer industry and pushed away by the obsolescence of many university's facilities. Furthermore, linking the computer science departments to ARPANET was out of question, due to the high cost involved in participating to the ARPANET research program. HAFNER, LYON, p. 241-2.
} 
financing for a new infrastructure ${ }^{38}$. The experience accumulated by NSF in the process of starting up CSNET paved the way for further interventions in computer networking.

The privilege of accessing the government funded CSNET was granted only to personnel in the computer science field. Their colleagues soon began to complain that their own communities needed to be network connected as well.

In the middle of the $80 \mathrm{~s}$ all research scientists came to believe they were at a competitive disadvantage unless they had network access. An agitation soon arose to interconnect five supercomputers created in 1985 around the country ${ }^{39}$ through a new «backbone» to be financed by the agency. NSF did not have the means to build a national network (maintaining the ARPANET alone cost millions of dollars a year); therefore the Congress authorized the National Science Foundation to create what in 1985 would become NSFNET.

\section{(ii) NSFNET}

NSF agreed on building the backbone network ${ }^{40}$ of the new NSFNET, to which also regional networks could connect ${ }^{41}$. In response, a dozen non-profit regional networks were formed

38 Linking the computer science departments to ARPANET was out of question, due to the high cost involved in participating to the ARPANET research program (HAFNER, LYON, p. 241-2). NSF jump started the network providing \$5 million for a five years start-up period, after which it was to be fully funded by users fees. At the end of the 5 years period of NSF support, in 1986, nearly all the country's computer science departments, as well as a number of private computer research sites, were connected (HAFNER, LYON, p. 243). Hafner and Lyon claim that after the 5 years period the network was self-sufficient but this is highly questionable. That service would have been fundable without government financing only if its benefits were superior to any private alternative. However it is not possible to speculate about this possibility, since in the subsequent years the government agency embarked in grander public financed projects that provided the same type of service, that is, providing a network connection to the whole academic community.

39 JVNC at Princeton, PSC at Pittsburgh, SDSC at UCSD, NCSA at UIUC, Theory Center at Cornell.

40 The transmission speed of this backbone was 56Kbps. Quarterman, CarlMitchel, p.27

41 HAFNER, LYON, p. 245 
around the country ${ }^{42}$, each one having the exclusive franchise in the region to connect to the NSFNET backbone. NSF provided the backbone essentially as a «free good» to the academic community in the sense that the regional networks did not pay to use it ${ }^{43}$.

It is interesting to note that, by now, in the common language a distinction had emerged between words «internet» and «Internet» (with capital «I»): «internet» meant a private network (using the TCP/IP protocol), while «Internet» meant the public, federally subsidized network (that was made up of many linked networks, all using TCP/IP) ${ }^{44}$.

(iii) Merit

After significant congestion problems due to overwhelming demand for networking services that saturated the backbone in 1987, NSF upgraded the NSFNET backbone. It did so by signing a cooperative agreement with Merit Inc. ( a joint venture of IBM, MCI, and the University of Michigan ${ }^{45}$ ), which won a five-year contract to manage the network and oversee upgrades ${ }^{46}$. The new backbone gradually supplanted ARPANET ${ }^{47}$ as the national backbone.

42 CERFnet, NYSERNET, BARRNET, WESTNET, SESQUINET, NorthWestNet, PREPNET, JvNCNet, MIDNET, SURANET, and NEARNET. Martin Irvine, William Drake, Earl Dowdy, (Internet Industry History, 1999, http:/ / cct.georgetown.edu/ curriculum/505-99/internet3.html). SDSCNET, JVNCNET, SURANET, and NYSERNET were NSF-funded (Hobbes' Internet Timeline by Robert H Zakon, http:/ / www.zakon.org/robert/internet/timeline/ - 1980s).

43 On the other hand NSF grants to universities to connect their campuses to the regional network were always two-year, strictly non-renewable grants. This meant that after two years, universities were paying the cost of the regional connection out of their own pockets. HAFNER, LYON, p. 246

44 HAFNER, LYON, p. 245

45 In the Merit proposal to NSF IBM committed to $\$ 10$ million in «equipment, installation, maintenance, and operation»; MCI committed to \$6 million in «reduced communication charges»; the State of Michigan committed \$5 million «for facilities and personnel». Frischmann, p. 12.

46 The transmission speed of this backbone was 1.544Mbps (T1). Quarterman, Carl-Mitchel, p. 27

47 ARPANET was finally decommissioned in 1990. 
Although the primary objective behind the initiative remained "getting researchers access to supercomputers and large databases, and facilitating collaboration via electronic communication», the shift from a procurement relationship to a cooperative agreement marked a transitional point in the evolving government-industry relationship ${ }^{48}$. Indeed, it allowed NSF to maintain its active role in the evolution of the network (that is, its control) without having to provide maintenance and public funding to the network.

Here we have a clear example of distortion of economic calculation. The decision making process was controlled by an economic agent that did not have any incentive to minimize long term costs. At the same time, the firms that did manage to take care of the network maintenance were driven by the following incentives: a) secure solid and stable contracts with the public administration, b) obtain as much as possible as know-how in order to acquire a competitive advantage against competition; c) keep playing a first order influential role in lobbying.

The fact that government would seek to leverage private expertise is understandable since, with the lifting of the restrictions on private enterprise in the telecommunications sector ${ }^{49}$, the industry was now allowed to provide the expertise needed in the development of an efficient network. However, Frischmann and others here maintain two questionable points about the cooperative agreement: first, the know-how obtained by industry participants facilitated technology transfer; second, it brought commercial interests and objectives into the planning process.

These claims are weak because the technology transfer remained localized to the stakeholders of the agreement that, on the contrary, did their best to leverage their unique position in the management of the NSFNET backbone, as Frischmann himself admits ${ }^{50}$. Furthermore, the expectable push toward commercial use of the Internet would be hindered in the subsequent years by the NSF's Acceptable Use Policy (AUP).

\footnotetext{
48 Frischmann, p. 13.

49 See previous section, the 1982 lift up of the 1956 consent decree.

50 Frischmann, p. 16.
} 


\section{(iv) Acceptable Use Policy}

This policy, drafted by NSF in 198951, allowed exclusively for the transport or interconnection services over the backbone for purposes «in support of Research and Education». More specifically, the AUP generally prohibited any traffic of commercial nature over the public NSF backbone ${ }^{52}$. This restriction gave rise to significant tensions because (1) local and regional networks desired commercial traffic in order to spread their costs and thereby to lower subscriber prices and (2) commercial interests wanted access to the backbone ${ }^{53}$.

At that time, commercial companies accessed the Internet through the regional networks, also known as mid-level networks, which were generally organized as nonprofit associations of the academic institutions that they served. These networks typically enforced the NSF AUP, but provided Internet access for many commercial companies ${ }^{54}$. Although technically this could have been defined as a "commercial use» of the Internet, it would have been a far unacceptable restriction to forbid private users and companies to access the same resources that were available to academic and government employees ${ }^{55}$. Still, selling over the Internet (the activity that years later would have been labeled E-Commerce) was out of question.

The first local experiments in providing Internet services free of the AUP took place at the beginning of 1990, when

51 OIG Review of NSFNET, April 23, 1993, p.37, http:/ /www.nsf.gov/pubs / stis1993/oig9301/oig9301.txt

52 However, the AUP explicitly permitted the use of the Internet by for-profit organizations where this use was «covered by the General Principles or as a specifically acceptable use.» This allowed the engineering departments of private companies (especially those in computer and communications companies) to use the Internet for Research and Development activities. Robert Larribeau Jr., «Internet Providers: The Future for the Commercial Internet Service Providers», The Internet Business Journal, Volume 1, Number 2 - August, 1993, http://lists.village.virginia.edu/ lists_archive/Humanist/v07/0233.html

53 Frischmann, p. 15.

${ }^{54}$ Larribeau, supra note 50.

55 The NSFNET backbone was funded with taxpayers money, and even though this made the agency very sensitive about it's usage, denying the use of it to the citizens that had paid for it would have been seriously criticable. 
Performance Systems International (PSI), UUNET and CERFnet started offering internet access that did not require conformance to the NSF Acceptable Use Policy on their «own networks» 56 . The first challenge for PSI, UUNET, and CERFnet was to provide an NSF AUP-free path for their customers to communicate with each other. At the time they were formed, these providers were interconnected by the NSFNET backbone. This meant, for example, that a PSI customer communicating with a UUNET customer had to conform to the NSF AUP. These three networks were isolated islands of commercialization that had to be bridged.

(v) Advanced Network \& Service, Inc

In the meantime, the relationship between government and industry evolved as congestion on the backbone needed another upgrade. In September 1990 Advanced Network E Service, Inc. (ANS), a non-profit company, was formed by IBM, MCI, and Merit, Inc. to implement and operate an upgraded backbone for the NSFNET ${ }^{57}$.

At this time Frischmann reports that a momentum towards «privatization» and «commercialization» of the Internet emerged as an important objective for both government and industry ${ }^{58}$. It is undeniable that those businesses that had a relationship

56 PSI was formed in 1989 as a spin-off from the NYSER-Net, a nonprofit academic network based in Syracuse, NY. UUNET began offering UUCP based information services in 1987. It created its AlterNet network in 1990 to provide Internet services. A third network, CERFnet, which provides AUP-free services in California was formed in 1988. Larribeau, supra note 12.

57 IBM and MCI contributed private funds (\$4-6 million), personnel and equipment to ANS and obtained a significant equity interest in the upgraded network. Frischmann, p. 16. The transmission speed of this backbone was $45 \mathrm{Mbps}$ (T3). Quarterman, Carl-Mitchel, p.27

58 To this end it is appropriate to define what we mean with "privatization» and "commercialization» of the public network. The former deals with the entities that operated the equipments that provided the network service. The latter has to do with the users of the Internet, allowing them the right to provide or consume commercial services over the net. 
with the government were interested in leveraging their privileged position to get their stake in a future privatization. Moreover, inside the institutions that participated in shaping the future of the Internet there was a debate about a possible shift of the dominant government objective from «research and education» towards «commercialization» ${ }^{59}$. However, at this time, the AUP was fully in place and subsequent presidential and congressional events, which we will analyze later, kept for a while a climate of political uncertainty for private enterprises that could offer commercial services over the network.

In 1991 alternative and competing means of providing AUPfree access to the Internet emerged. In March, the three islands (PSI, UUNET, and CERFnet) formed the Commercial Internet Exchange (CIX), to provide a direct AUP-free interconnection among the participants. The "CIX became, in effect, a commercial version of the Internet, offering the same set of connections to a different clientele» ${ }^{60}$. Soon after the commercial Internet providers started business, though, a significant event in the development of the Internet occurred.

(vi) Commercial plus Research and Education

In May ANS formed a wholly owned for-profit subsidiary called $\mathrm{CO}+\mathrm{RE}$ (Commercial plus Research and Education), to serve commercial customers and link them to the academic community. While this was a privilege denied to its commercial competitors, it was generally justified by that fact that ANS's sponsors (IBM and $\mathrm{MCI}$ ) had spent far more on providing the network than what they received from the US government. ( $\$ 60$ million total expenditure compared to $\$ 18$ million in Federal

59 See for example the workshop held at the John F. Kennedy School of Government, Harvard University March 1-3, 1990, by the Harvard Science, Technology and Public Policy Program. Sponsored by the National Science Foundation and the U.S. Congress Office of Technology Assessment, the workshop was designed to explore the issues involved in the commercialization of the Internet. http:/ / www. cis.ohiostate.edu/cgi-bin/rfc/rfc1192.html

60 Frischmann, p. 18. 
funds was an estimate given by Steve Wolff, NSFNET Director in July of $1991^{61}$ ).

The creation of the $\mathrm{CO}+\mathrm{RE}$ gave rise to considerable and justifiable concerns among commercial network service providers who protested against the shift of the control of the backbone from a pure nonprofit, Merit, to a nonprofit with a commercial subsidiary ${ }^{62}$.

This apparent shift toward privatization without commercialization is quite easily criticized. With the prohibitions over commercial use of the Internet and the repeated privileges conceded to only few selected private partners, NSF chose the most harmful way to privatize the Internet. The privatization of a governmentfunded good should be handled in a way that does not introduce distortions in the market processes that the shift could jump start. Here exactly the opposite happened. The emergence of competitive long-haul private networks was not a direct consequence of NSF's policies ${ }^{63}$, which actually represented a concrete obstacle to healthy free competition in the development of the sector ${ }^{64}$. This scenario

61 However, a degree of doubt was cast upon this assertion in late 1992 when ANS's first Form 990 became available and showed expenditures for the backbone that roughly equaled income from Federal grants. Gordon Cook, NSFnet «Privatization» and the Public Interest: Can Misguided Policy be Corrected?, The Cook Report, 1992, http:/ / www.cookreport.com/p.index.shtml

62 Frischmann, p. 16.

63 As Frischmann maintains at p. 17.

${ }^{64}$ Gordon Cook (supra note 59) accounts of two notable episodes that at this point. Episode 1:

«ANS had been trying to get many mid-level customers to buy direct connections to it». "At the end of 1991 [...] Dialog was announced as ANS's first commercial customer and those mid-levels that had not yet signed the ANS connectivity agreement were blocked from connection. This made the impact of ANS's exclusive right to move commercial traffic across the former NSFNET backbone apparent to all. The resulting angry dispute made the New York Times and in January of 1992 Dialog was allowed to become an R\&E customer of ANS so that it could be reached by the entire network.»

Episode 2:

«In 1992, faced with pressure from the network community to give up its insistence on settlements and join the CIX, ANS agreed to connect to the CIX so that networks which were already CIX members could use its backbone to send data to the CIX.» 
of uncertainty was worsened by a new initiative in Congress, which looked like a round stop the Government retreat process that the main observers were expecting.

(vii) National Research and Education Network

Because of government and industry members concerns over what they perceived to be a high-technology lag in the U.S., compared to other countries, in 1989 the President's Office of Science and Technology Policy had issued its Federal HighPerformance Computing Program report ${ }^{65}$. The report proposed a three-step process with which the federal government would fund a new network (National Research and Education Network NREN), based on the NSFNET. The NREN could eventually transmit data at higher speed ${ }^{66}$ and would extend not only into the traditional research, university, and government arenas, but even into selected elementary and secondary schools. Once the network was built, it would gradually be commercialized, or run by commercial organizations instead of the government. In 1991, Al Gore successfully persuaded Congress to pass the High Performance Computing Act (HPCA), a law that suggested the concept of a national «data superhighway» and which called for funding of the proposed NREN to link educational institutions. The objections to the bill expressed a growing concern that the government was taking too large a role in the building of the Internet, and that it was giving an unfair advantage to a few selected enterprises ${ }^{67}$.

At a time when private enterprises where hoping for the government to give up the management and control of the Internet, a new step of government funding for the new network was proposed. After ARPANET and NSFNET, now NREN appeared to be the new milestone in the history of the Internet.

\footnotetext{
65 Sharon Fisher, «Whither NREN?», Byte, July 1991, http:/ / www.byte.com/art/ 9607/sec4/art1.htm\#076bl1c2

66 In the order of the Gbps.

67 Fisher, supra note 63.
} 
It involved a new round of public funding for the new infrastructure, with government selecting the appropriate commercial participants, followed by a transition period for privatizing the NREN.

We should not forget that 1992 was the year in which the 5 years contract assigned to Merit, back in 1987, expired ${ }^{68}$. To those observers that were expecting the transition period to start at the end of the contract, this new initiative sounded like a round setback. Many opposed the new initiative because they believed the new infrastructure that the government wanted to create was already in place. To this end Sharon Fisher reports various comments of people concerned that the economy did not need the government to drive the next step in the evolution of the Internet ${ }^{69}$.

With interested parties worried about a new episode of government planning the future of the net, we can now turn the attention to the events that led to the «commercialization» and «privatization» of the Internet.

68 Merit's contract with the NSF for running the NSFnet backbone expired in October 1992. Fisher, supra note 63.

${ }^{69}$ Fisher, supra note 63.

Comment 1:

«It depends on your view of NREN,» says Martin Schoffstall, vice president and chief technical officer for Performance Systems International (PSI), which provides a commercial network service and a portion of the existing NSFnet backbone. «If it's a funding device for the grade schools or the high schools or the local libraries or the community colleges to participate in the Internet, then it is needed. If it means building a big network, owned and controlled by the government or by some contractor, then it probably is not [needed].»

Comment 2:

Many believe that the best way for the government to develop a network is to support existing services rather than to build another network. «The Internet, up to now, has been this wonderful socialwelfare state,» says Geoff Goodfellow, president of Anterior Technology, in Menlo Park, California, which provides Email and news feeds. "Not to say that the Internet hasn't been a good thing," Goodfellow adds, «but we're now at that turning point when those commercial carriers can provide the same level of service that the government backbone can. Then it's time for the government, rather than funding the backbone, to put the money in the hands of the subscribers of the network and let them pick the 


\section{Commercialization and Privatization}

a) Information Superhighway

The idea of building a data superhighway (which was rooted in Al Gore's HPCA of 1991) to stimulate the U.S. economy was explained in the Democratic presidential campaign in 1992. With the country not yet out of the 1991 recession $^{70}$, Bill Clinton and Al Gore put forward as one of the key component of their economic reconstruction policies the idea of an «Information Superhighway», a term that they repeated thousands of times ${ }^{71}$. Typical of a political campaign promise, it was not exactly clear to the public what this new network was concretely meant for. Reiterated requests for explanation finally pushed them to define the goal of connecting all the country's classrooms, an objective which was perfectly in line with a new big NREN government network envisioned by $\mathrm{Al}$ Gore.

In the meantime, at the end of 1992 the shift toward privatization of the Internet began. The Scientific and Advanced Technology Act of 1992, introduced by Congressman Boucher and signed into law on 23 October 1992, subtly modified NSF's authority to support computer networks that were not limited to research and education $^{72}$. However, this was not a commercialization yet ${ }^{73}$,

network service provider they wish to go with, along the same lines that they would pick a long-distance carrier.»

\section{Comment 3:}

«We want to eliminate, if possible, the chilling effect that some of these policies have. Folks are worried about whether they are in compliance with the acceptable-use policies.» Joel Maloff, former vice president of client services for Advanced Network and Services (ANS).

70 Joseph Stiglitz, Los Felices 90, Taurus, Madrid, 2003, p.74. Spanish edition of The Roaring Nineties.

71 John Cassidy, Dot.con: The Greatest Story Ever Told.

72 OIG Review of NSFNET, super note 14.

${ }^{73}$ The Act said: «Thus, NSF is now authorized to support 'research and education access' to networks that are used primarily for commercial purposes, 'but only if' allowing commercial use will enhance the networks' utility 'for research and education». 
because it did not address the fundamental AUP ban of sales and advertisement ${ }^{74}$ over the net.

The privatization proceeded quickly with two further steps. In November 1992, the responsibility for managing NSFNET Network Operations was taken over by ANS ${ }^{75}$. In December 1992 the NSF announced that it would stop its subsidy of the Merit-supplied NSFNET backbone, although the contracts were extended until 1995 to ensure a continuous expansion of connectivity.

When Clinton and Gore took office, at the beginning of 1993, they soon realized that their promise of providing an Internet connection to every American classroom was not feasible. This would cost a fortune, something like one trillion dollars ${ }^{76}$, equal to the entire federal budget income for the year 1993. Considering the strict budget discipline that the Clinton Administration imposed on itself because of the huge federal deficit they inherited (in 1992 deficit amounted to 4,7\% of GDP), the idea of making a further step in heavy government financing of the development of the Internet was quickly abandoned. They opted for passing this task to the private sector in a way that would quickly lighten public spending, that is, by speeding up the privatization process. That is why, from the legislative point of view, privatization and commercialization of the Internet effectively began within the frame of the 1993 political agenda.

\section{b) National Information Infrastructure}

The Clinton Administration immediately began to work on a new plan (National Information Infrastructure - NII) that would

${ }^{74}$ John S. Quarterman, Smoot Carl-Mitchel, The Internet Connection, 1994, Addison Wesley, p.56

75 Merit, however, retained responsibility for providing NSFNET backbone services. Jeffrey K. MacKie-Mason,Hal R. Varian, Some Economics of the Internet, (1992), paper prepared for the Tenth Michigan Public Utility Conference at Western Michigan University March 25-27, 1993

76 John Cassidy, supra note 69. 
lift the government from the financial commitment of creating a new network and at the same time would keep the promise of creating more internet connections for the educational system. The Congress began to address the issue in terms of privatization and the NSF committed to submit its proposals. It was at this time, in March 1993, that the NSF, in an attempt of clear up the debate over the advantage that was given to ANS, decided to reinterpret the AUP to allow more commercial traffic over the NSFNET backbone. By stating that the NSF was only a customer of ANS, the AUP was interpreted to mean that ANS was free to use its portion of the backbone without restrictions. This was only a partial answer to the question of the acceptability of the use of the network for commercial traffic. While this did not satisfy the objections that many had over the «unfair advantage» that was given to ANS, it did help to show that the NSF was willing to consider commercial traffic over its network. Even if it did not satisfy everyone, it was an important step in commercializing the Internet ${ }^{77}$.

The House passed The National Information Infrastructure Act of 1993 on July 26, 199378. The Act amended the HighPerformance Computing Act of 1991 by making it specific that government funding would not go to «the network» in general, but only to «Federal test bed networks», where the research need of educational institutions could be met. The amendment also instructed the developers of the new network to purchase or contract «standard commercial transmission and network services," as well as to use materials from the private sector in the development of the network. The plan was to privatize the existing NSFNET backbone, while at the same time creating a new network for research named the «National Research and

77 John Thomson, Jr., Privatization of the New Communication Channel: Computer Networks and the Internet, 2000, http://www.sit.wisc.edu/\%7Ejcthomsonjr/j561/ NSFpolicy-7.html

78 Was then introduced in the Senate as part of the National Competitiveness Act of 1993. A copy of the NIIA can be found at: http: / / www.interesting-people.org/ archives/interesting-people/199309/msg00076.html. On September 15, 1993, the U.S. government issued the National Information Infrastructure Agenda for Action (NII Agenda for Action), which effectively implemented the plan. 
Education Network» (NREN). The privatization took place with the creation of a new network architecture proposed by the $\mathrm{NSF}^{79}$. This awarded contracts in 1994 to four companies ${ }^{80}$, which would have provided access to the NSF backbone selling connections to groups, organizations, and businesses. Finally, as of April 30, 1995 the NSF no longer allowed direct access to the NSF backbone.

\section{c) The effective dates of Commercialization and Privatization}

The legislative shift was completed by the end of 1993 and its rapid implementation in 1994 clearly took the development of the Internet out of the hands of the government and placed it into the hands of the competitive marketplace. By 1995, all the private network providers that previously were not allowed to offer access to the Internet were connected to it. Among these we shall remember the major ones: Compuserve (the first one, established in 1969), America On Line - AOL (funded in 1982, the only one that did an IPO before the commercialization, in 1992), and Prodigy (1990).

To allow an economic analysis about the way the processes of commercialization and privatization were carried out, it is useful to fix some points that emerge from the historical account we just described.

First, the real commercialization of the Internet, that is the authorization to use the public network for any type of commercial activity (not only access for R\&D, but also advertisement and

79 Were created Network Access Points (NAP), new major network nodes through which all of the major commercial Internet Service Providers (ISP) could connect to the existing Internet. Regional and local networks would have paid commercial ISP for interconnection services. NSF also selected MCI to provide a very high speed backbone service linking the NAPs (initial transmission speed: $155 \mathrm{Mbps}$ ). Finally, a Routing Arbiter would manage the «ever-growing routing tables and databases for the providers connecting at the NAPs. Frischmann, p. 20.

80 NAP Manager awards were given to different private companies, for example, to Sprint (for the New York City NAP), MFS Datanet (for the Washington, D.C. NAP), PacBell and Ameritec. 
sales) came at the beginning of 1994. The first business plans to provide services over the network in a completely free competitive environment were allowed to be drafted starting from that moment.

Second, the privatization was implemented in 1994. It was a process that had not been announced years in advance and that took place in a very short time period. Orthodox economic theory often argues that sometimes market forces are not driven by the right incentives because of poor time horizons. In the case of the privatization of the Internet, it is hard to maintain that private business was given enough time to carry out solid long term planning.

Finally, since free competition in the Internet access market was in place only at the beginning of 1995, and taking into account that the Internet commercial services (again, not only access) needs Internet access by definition, we can conclude that the provision of a full range of commercial services over the Internet began to be feasible in 1995 as well.

In conclusion, day one for the free enterprises that wanted to act in absence of governmental restriction was the beginning of 1995.

\section{Economic Analysis of the 1995 period}

We have seen how the birth and the development of the Internet was influenced by government restrictions. The legislature laid down multiple barriers that in some cases forbid private initiative, and in others shut down the business incentives to offer Internet services. This, in turn, promoted the absence of competition.

By banning the use the publicly funded network for commercial purposes and by conceding privileges to selected private partners, government intervention inhibited, ipso facto, the creation of a market in the rising Internet sector.

The shift from government-control to market-control of the network allows at least for two observations that economists should not undervalue. First, the privatization represents an interesting counterexample to the orthodox market failure model. 
Second, the commercialization implied a previous period of restrictions that had a negative impact in the development of the Internet services. In the following sections we propose an economic analysis of these claims.

\section{a) Market and government failure}

Neoclassic economics maintains that market forces generally provide an efficient supply of the goods and services required by society, on the grounds that the right profit incentives drive the entrepreneurs to meet the consumer demand.

Government intervention is considered appropriate by neoclassic economists when goods and services are undersupplied with respect to the market demand. This happens when, due to high fixed costs, proper profit incentives are not in place to attract entrepreneurial ventures. The reasons for this market failure are usually explained with arguments such as imperfect or asymmetric information, transaction costs, or attenuated time horizons. In this case, government intervention can either fix the deficiency in the market mechanism or directly provide society with the good or service ${ }^{81}$.

In our analysis of the birth of ARPANET and the commercialization of the NSFNET, we demonstrated that the lack of incentives for action on the side of the market forces was not due to high fixed cost but to previous government intervention that restricted or prohibited the entrepreneurial function. In this case, government action was not justified because the conditions for claiming the applicability of the market failure model were not in place. This clearly explains why the wrong (failed?) application of neoclassical theory led to a distorted development of the Internet.

In any case, the process was put into motion: in the 70s and in the 80 s government intervention provided innovation and

81 Frischmann, p. 43. The rest of this paragraph is inspired by Frischmann's section III.2: The Past: Justifying Market Intervention into Government. 
the network infrastructure (however, nobody can claim how the Internet would have been developed in absence of such disturbance ${ }^{82}$ ).

A further problem arises when we consider the shift from public to private provision, which occurred at the end of the 80 s. One could argue that after the initial stage of government funding, government intervention in the market was no longer justified because the market could adequately steer private investment into the Internet infrastructure.

However, this wasn't the rationale behind the privatization. As we have seen, the government retreat was imposed by budget constraints. In other words, we are facing an event in which the government is not able to cover the fixed cost required to provide a service that society demands, while at the same time the market has the right incentives to provide those funds. This is a plain case of government failure that requires a free market solution.

Orthodox theory assumes that market failures can always be cured by government intervention because the latter has unlimited resources. This hypothesis is completely unreal and calls into question the economics behind it. Although cases of government failure that require market intervention are known to conventional theory, this one would deserve further consideration $^{83}$.

82 Peter Klein, «Government Did Invented the Internet, but the Market made it Glorious», Mises Daily, 6/12/2006.

83 Unfortunately, the author that inspired this paragraph does not address the point. Instead of calling for a revision of the conventional thought, Frischmann argues about concerns over an overextended privatization and commercialization that could produce «undue interference with the government provisional mechanism. To be more precise, market intervention into the government should be limited to correcting the government failure». All of this under the clairvoyant's type of assumption that, although at the moment the right incentives are in place to drive the market, we don't know if in the future this will still be the case. 


\section{b) The Entrepreneurial Function}

Were the commercialization and the privatization of the Internet carried out in the right way? Did they allow for knowledge transfer from government-driven enterprises to private business? Was the information poured from government ventures to the private entrepreneurs of the kind the sector actually needed? To answer these questions we will profile how the entrepreneurial process works, following the Austrian paradigm.

The entrepreneur is a creative actor who seeks to solve situations of social discoordination, because these implicate profit opportunities ${ }^{84}$.

A situation of social discoordination can be described by the following example. Two individual actors pursue each one a subjective goal that is not related, not to say in contradiction, with the one of the other. To reach his end one of the actors lacks a mean that is owned by the other, who does not know what to do with it.

An alert entrepreneur recognizes that there is business opportunity ${ }^{85}$ in this social discoordination. He could act as an intermediary in order to solve the problem by buying the underused resource, eventually elaborating on it, and selling it as a service or good to someone who needs it. In doing so, he creates information. Furthermore, he will go on envisioning an image of the plan for providing that service or good, namely a business plan (a subjective one) that implies a series of tasks. By drafting a business strategy, organizing the production of the good or service and taking it to the market, he further creates information, which is nothing but a refinement, a specialization and an application of the one previously created.

At the moment of the commercial exchange, this information is transmitted to the buyer who will learn about a new opportunity

84 J. Huerta de Soto, Socialismo, Calculo Economico y funcion Empresarial, 1992, Union Editorial, Madrid. An English translation of cap. II and III, can be found in «Entrepreneurship and the Economic Analysis of Socialism», in New Perspectives on Austrian Economics, Gerrit Meijer, ed. (London: Routledge, 1995).

85 J. Huerta de Soto, Ibid., p. 57. 
to satisfy his subjective needs. The sale is also a confirmation for the seller (that is, further refined information) that his entrepreneurial appraisal was right. Moreover, this information is transmitted to the observers of the transaction ${ }^{86}$, since it is condensed in the market price established in the exchange. This is why prices become a sort of signal; they summarize the constellation of subjective knowledge ${ }^{87}$ disseminated in the mind of the exchange's participants. The price of a business transaction represents, in other words, a historical trace of the exchange just happened and that tomorrow will inspire others to venture on a similar (further information transmission) or new (further information creation) course of action.

After the entrepreneurial act, all the actors that took part in the business transaction are better off ${ }^{88}$. Those who were affected by the social discoordination will be able to reach a subjective goal that previously was unsatisfied, while the entrepreneur will obtain a profit from it.

\section{c) Capital Structure and Knowledge Structure ${ }^{89}$}

In order to offer goods and services, the entrepreneur must go through a process of production that requires time and that employs those means of production that he subjectively believes appropriate. A mean of production is also called «capital good»,

86 J. Huerta de Soto, Ibid., p. 65.

87 There are two kinds of information (or knowledge) available to the economic actor: the objective one and the subjective one. Subjective knowledge is the one that is relevant to the end of the entrepreneurial act (Huerta de Soto, Ibid, p. 52). Of course objective knowledge does exist and is employed as well by the entrepreneur, but it is not the one that is relevant for the entrepreneurial function. Hence, in this work (unless otherwise specified), when we mention information or knowledge, we refer to the subjective one.

88 The wording «better off» should be interpreted in this subjective way, without pretending to introduce any objective metric that describes «how much» people are better off.

89 This paragraph supposes that the reader is familiar with the standard notion of capital structure by Menger (see Menger, 1994, cap. II and Huerta de Soto, 2002, p. 233) and with the theory of capital by Bohm-Bawerk (see Huerta de Soto, 2002, p. 218 and Hennings, 2001, cap. VIII). 
while its value (intended as the subjective estimation of the individual actor) at the current market prices is defined «capital» ${ }^{90}$.

Accumulating capital goods ${ }^{91}$, successful entrepreneurs create information that can be valued and become, in itself, capital. As a matter of fact, when a product is sold it is not its material composition that determines its value. The buyer acquires it for some use, and it is precisely the subjective valuation of what he intends to do with it that determines its usefulness for a given price. If we think in terms of capital goods, this is quite clear. A hammer is not evaluated for being a piece of wood with a piece of iron on the top of it but, on the contrary, for its usefulness in knocking in a nail. A machine to can cigarettes it's not merely a set of complex mechanics and electronics; a computer program or a Internet connection are not only a thousand lines of code or a physical connection to a server. What we buy is in reality the subjective image of it as a mean for our ends. We don't know how the Internet connection works, we are not interested in the knowledge embodied in it, we just want to acquire that capital good in order to use it.

By acquiring the good we implicitly gain possession of that knowledge. This information has been created and accumulated in it by the previous efforts of entrepreneurs that finally discovered which product to sell. At a particular point in time and place, it was exactly that hammer, that machine, that program or that Internet connection that the consumer wanted to buy for a particular price ${ }^{92}$. Ergo, a capital good embodies knowledge ${ }^{93}$.

Since a capital good represents a mean that is subjectively selected by the entrepreneur accordingly with its business plan,

90 Huerta de Soto underlines that some Austrians (Hayek, Lachmann) have employed the term «capital» in a less strict way, to refer to the set of capital goods that constitutes the structure of production. Jesus Huerta de Soto, Dinero, Credito Bancario y Ciclos Economicos, $2^{\text {nd }}$ Ed.,Union Editorial, Madrid, 2002, p. 226. (English edition, Money, Bank Credit, and Economic Cycles, Ludwig von Mises Institute, Auburn 2006)

91 The sine qua non condition for producing (and/or being able to buy) capital goods is saving, intended as the act of renouncing to immediate consumption (that is, deferring consumption) in order to accumulate resources. Huerta de Soto, Ibid, p. 218.

92 Considering, obviously, the collection of conditions enclosed in the sale's contract.

93 From an objectivistic point of view, other elements implicitly included in a capital good are the natural resources and the labor employed to build it, as well as the time needed to its process of production. 
its monetary value (capital) is strictly connected to the use he intends for it. It is precisely the subjective plan of the entrepreneur that has been selected according to the information at his disposal what has been created.

Along his path, the entrepreneur accumulates know-how, improves the technologies he employs, progressively introduces in the market more advanced products that day by day embody more knowledge, more capital.

Through the division of knowledge, his venture specializes in core businesses that are more and more specific. The knowledge embodied in the capital goods he offers for sale increases and, at the same time, narrows down for more specific uses. In the mean time, the production structure becomes longer and more complex. That means a rise in the number of intermediaries that intervene in the construction of a product or service, before it reaches the consumer.

As the production structure grows, so does the capital structure, that is the capital employed in every stage of it. So does also the knowledge structure, which is the knowledge represented by that capital.

So we see how the simple act of choice carried out by the consumer allows the intertemporal building of a knowledge structure that meets precisely its wants and for this reason justifies the whole and complex universe of capital invested in it.

\section{d) Absence of a Knowledge Structure}

When the federal authorities authorized the commercial use of the Internet, the industry was unprepared to handle the situation. This is not to say that entrepreneurs were unable to face new opportunities in a field that, until then, had been obscure to them. Indeed, business was finally allowed to put in motion the law of supply and demand; in other words, entrepreneurship was ultimately authorized to solve the situations of social discoordination that were latent on the network.

The problem is that at day one of the commercialization, a knowledge structure did not exist for the internet services sector. 
Since nobody before had been allowed to explore business opportunities «over the Internet», in 1995 the knowledge of what to offer, at what price and how to build it simply did not exist. Nobody in this sector had previously accumulated know-how, that is capital. A capital structure, a knowledge structure did not exist ${ }^{94}$.

The reader should not confuse the concept of «Internet access» with the idea of «commercial services over the Internet». The former involves the privatization of the network infrastructure and the market structure for simply providing the access to the Internet. The latter is related with the commercialization and the cloud of services that one has at his disposal once he is already online. The distinction is important because while for the first one a capital structure already existed, though underdeveloped and distorted by the multiples government interventions we have illustrated, in the second case the knowledge structure did not exist at all.

\section{e) Distortions induced by government intervention}

What happens to a new market, which has the potential to grow exponentially, if a knowledge structure for it does not exist? We have seen that a knowledge structure is developed along a period of time, as consumers begin to express their preferences among an array of services offered thanks to a new groundbreaking technology. It takes time to build a knowledge structure that actually attracts further capital investments.

Entrepreneurial ventures, selected by consumer choice, advance on a "trial and error» basis ${ }^{95}$. This process, which had been literally sabotaged and suffocated until 1995, is a powerful one and would have gone toward the right direction, that is, solving situations of social discoordination. The only fragile

94 Even if at this point in time the concept should be sufficiently clear, it is not redundant to repeat that when the spontaneous working of the market is suffocated by regulation, the consumers won't be able to «reveal» their preferences. This in turn dazzles the path toward the development of the information and production structure, because it shuts down the acquisition of information on the side of the entrepreneurs.

95 Mises express this concept in the clearest way. «The entrepreneurs and capitalists do not have advance assurance about whether their plans are the best appropriate 
points in this process are external interferences. The factors that distorted this market process can better analyzed from the consumer side and from the production side.

\section{(i) Consumer preferences' occultation and distortion}

We have already seen that government intervention deviated from the spontaneous evolution of the sector. This implies also a change in the consumer's value scale ${ }^{96}$. Clearly a buyer adapts his behavior to the products the market offers, he cannot be aware about opportunities that did not emerge because of government constrains ${ }^{97}$.

Before 1995, two factors pushed public opinion toward the idea that Internet Access should be free or, at least affordable to all: the relevant «opinion-makers» and the high "price of Internet Access» offered by private operators.

As far as opinion makers are concerned, we should take into account the high credibility enjoyed by those institutions (academic

solution for the allocation of factors of production to the various branches of industry. It is only later experience that shows them after the event whether they were right or wrong in their enterprises and investments. The method they apply is the method of trial and error.» (p. 704). "What the operation of a market not sabotaged by the interference of compulsion and coercion can bring about is merely the best solution accessible to the human mind under the given state of technological knowledge and the intellectual abilities of the age's shrewdest men. As soon as any man discovers a discrepancy between the real state of production and a realizable better state, the profit motive pushes him toward the utmost effort to realize his plans. The sale of his products will show whether he was right or wrong in his anticipations. The market daily tries the entrepreneurs anew and eliminates those who cannot stand the test. It tends to entrust the conduct of business affairs to those men who have succeeded in filling the most urgent wants of the consumers. This is the only important respect in which one can call the market economy a system of trial and error.» (p. 705). Ludwig von Mises, Human Action, third revised edition, Fox and Wilkes, San Francisco, 1963.

96 In the field of economics of transition, Prof. Colombatto proposes an interesting distinction between Neoclassical and Austrian paradigm. The former focuses on institutional engineering, while in the latter «the emphasis can easily shift away from institutional engineering, towards the analysis of the set of formal and informal constraints which affect individual behavior». Colombatto, 2000.

97 Unless, obviously, he identifies the solution for a social discoodination and ventures, if free to do so, in the attempt of solving it. 
and non-academic) that participated in the development of the Internet. These same institutions participated as well in the collection of the subsidies' waterfall lavished by the US Federal Government in the previous years. The opinion makers' elite gathered around these institutions and it is almost superfluous to note that their orientation reflected the incentives they had: preserve their (economic) status quo. The means to achieve this objective was of course to give support to the notion that the Internet had to remain a free public good and that in order to ensure this goal ... public subsidies were absolutely necessary ${ }^{98,99}$.

The price of private Internet access was higher that those provided by public and non-profit organization for four simple reasons:

a. Public and non-profit institutions discounted the advantage of the public subsidies.

b. The Government produced tailored legislation in favor of public and non-profit institutions.

c. Public and non-profit institutions had an unfair competitive advantage to connect to the network backbone in order to exchange traffic associated to its main mission (that for the business conversely had a commercial nature ${ }^{100}$.

d. Even in this case the typical effects of the distortion introduced in the private economy by the presence of government funded

${ }_{98}$ Further arguments maintained that the public network allowed to solve many social problems and contributed to a more efficient economy because it promoted a productivity increase.

99 It is remarkable that in 2007 the private market embarked in a new business model that offers free Internet access in exchange for the right to track consumer behavior. The role of the public administration involved (the City of San Francisco) and the related privacy concerns are an interesting topic to be developed further in a different study. See City Of San Francisco, «Wireless Broadband Internet Access Network Agreement Between The City And County Of San Francisco And Earthlink, Inc.», 2007 (http://www.sfgov.org/site/uploadedfiles/dtis/tech_connect/process / SanFranciscoWirelessNetworkAreementFinal.pdf) and Electronic Frontier Foundation, «Privacy Issues Associated with Municipal Wireless Internet Access», 2007 (http:/ / www. eff.org/Privacy/sfwsltrfinal.pdf)

100 See the previous section on the NSFNET and, particularly, the fact that the public backbone was provided essentially as a «free good» to the academic community in the sense that the regional networks did not pay to use it. 
projects (both public enterprises and project that privately run but publicly funded) were at work ${ }^{101}$.

The internet user of those times faced opinion makers sponsorship of a «public Internet» and the apparent inferiority of private networks' offering. This had an insidious influence on the consumers' perception of the service.

In conclusion, at the beginning of 1995, when the consumer preferences finally begun to drive from scratch the formation of an information structure, there was a clear public skepticism toward offering private Internet access.

(ii) Economic calculation distortion

In a previous section we have already mentioned an example of economic calculation's distortion (see Merit). In this section we develop further what happens when economic calculation has to be performed in absence of information or in the context of a very poor knowledge structure ${ }^{102}$.

Our thesis is that when the transition toward commercialization was already completed (that is, at the beginning of 1995), the lack of an information structure spontaneously built through a pure market process procured entrepreneurial errors. Because of this lack, the business models of the cloud of small firms that jumped into this new sector were developed in absence of the precious feedback that allows to build successes on the top of previous mistakes (in the typical entrepreneurial process of trial

101 «In addition, the establishment of government enterprise creates an «unfair» competitive advantage over private firms, for at least part of its capital was gained by coercion rather than service. It is clear that government, with its subsidization, can drive a private business out of the field. Private investment in the same industry will be greatly restricted, since future investors will anticipate losses at the hands of privileged governmental competitors. Moreover, since all services compete for the consumer's dollar, all private firms and all private investment will to some degree be affected and hampered». Rothbard, 1993, p. 823.

102 Economic calculation is a fundamental notion for the Austrian paradigm and indeed it represents the backbone of Huerta de Soto, 1992 (see p. 68 and ch.IV-VII). 
and error). In other words, the economic calculation performed by the first entrepreneurs of the Internet was distorted.

To support this thesis we will have to review briefly, from the praxeological point of view, why the lack of information introduces distortion in the economic calculation. Prof Huerta de Soto underlined the importance of the «bridge» existing between the subjective world of individual valuation (ordinal) and the external world of market prices estimations, fixed in monetary units (cardinal) ${ }^{103}$. This bridge is possible only if an action of interpersonal exchange is completed. Motivated by distinct subjective valuations, this action is traced by a monetary market price (also known as historical exchange relation in monetary units) which is a number that later may be taken into account as valuable information by the entrepreneur performing the economic calculation of his business activity. By impeding human action through coercion, the voluntary interpersonal exchanges are not performed. As a consequence the bridge between individual subjective valuations (ordinal) and market prices (cardinal), is broken, rendering therefore impossible the economic calculation ${ }^{104,105}$.

103 The bridge was first highlighted by Mises in the The Theory of Money and Credit (Ch 2. On the Measurement of Value) and Human Action, and by Rothbard in Man, Economy, and State.

104 See Huerta de Soto, 1992 (p. 169, n. 16), where he recognizes that this important extension of the Misesian thought was advanced by Rothbard in «The End of Socialism and The Calculation Debate Revisited». It is well known that inside the Austrian school there is a debate over the origin of the impossibility of economic calculation (lack of information vs. lack of private property of the means of production). In this debate some Austrians (following Rothbard and Salerno) tended to trace a strong line between Mises and Hayek over the elements that really influenced the possibility of calculation. Huerta de Soto (p. 73, n. 42 and p. 169, n. 16) recognizes the important contribution of both sides, by defining them two arguments of the same theoretical apparatus against socialist economic calculation. On the one hand, Mises was more focused on the aspects concerned with the dynamics of the problem. On the other hand Hayek may have been interpreted too strictly as if the problem was bound only to the dispersion of existing knowledge, and leaving aside the elements associated to uncertainty and future creation of knowledge (aspects that were highlighted by Mises). As a contribution to the debate, Huerta de Soto (p. 96-104) proposes the identification of two arguments against the practicability of socialist calculation, the first being a static argument (the Hayekian argument that the relevant information is not transmissible) and the second being a dynamic argument (taking into consideration Mises teachings).

105 Huerta de Soto also maintained that in simple situations, the actor holds already all the information needed to take a decision, that is, to perform economic 
To conclude the defense of our thesis, it is finally useful to remark a further aspect on the trial and error nature of the entrepreneurial process. Mises already advanced this concept ${ }^{106}$ and Kirzner splendidly extended it by stating that entrepreneurs tend to gradually discover the errors in the information that previously led them to malinvestment ${ }^{107}$.

Let us now move to the recent Austrian literature that identifies the consequences that arise when government intervention produces distortions in the market process.

Prof. Huerta de Soto argues that as a result of Government intervention and the concession of privileges to selected groups, the market indicators that usually drive the entrepreneur ventures

calculations. It is far more complex when the actor does not dispose of all the means he needs to pursue his goals; therefore he is forced to interact with other, that is, to take part in interpersonal exchanges. See Huerta de Soto, 1992, p. 57. However, I believe this point deserves further investigation. For example, shall I need to obtain further knowledge on what can I do with my internet connection in order to decide what to do with it?

106 «The sole way by which sellers can arrive at reliable knowledge about the valuations of consumers is the way of trial and error». The Theory of Money and Credit (Part II,Ch.8 in paragraph II.8.120 ). «What the operation of a market not sabotaged by the interference of compulsion and coercion can bring about is merely the best solution accessible to the human mind under the given state of technological knowledge and the intellectual abilities of the age's shrewdest men. As soon as any man discovers a discrepancy between the real state of production and a realizable better state, the profit motive pushes him toward the utmost effort to realize his plans. The sale of his products will show whether he was right or wrong in his anticipations. The market daily tries the entrepreneurs anew and eliminates those who cannot stand the test. It tends to entrust the conduct of business affairs to those men who have succeeded in filling the most urgent wants of the consumers.» Human Action, (Chapter XXVI. The Impossibility of Economic Calculation Under Socialism, 4 Trial and Error), p.704-5.

107 «The process through which the market tends to generate the «right» quantity of a commodity, and the «right» price for it, can be seen as a series of steps during which market participants gradually tend to discover the gaps or errors in the information on which they had previously been basing their erroneous production and/or buying decisions». "The market process is one in which, driven by the entrepreneurial sense for grasping at pure profit opportunities (and for avoiding entrepreneurial losses), market participants, learning more accurate assessments of the attitudes of other market participants, tend toward the market-clearing pricequantity combination». «Entrepreneurial Discovery and The Law of Supply and Demand», The Freeman, a publication of The Foundation for Economic Education, Inc., February 2000, Vol. 50, No. 2. 
result manipulated. These market signals allow the smooth rendezvous of the uncoordinated subjective valuations of the individual (that is, of the market discoordinations). However, if these market signals are suffocated (by government intervention), the economic information associated with them is not created and transmitted. This in turns impedes social coordination and creates further economic imbalances ${ }^{108}$.

Furthermore, Prof. Rothbard adds the concept of «islands of chaos». The presence of government intervention turns off the market process in a given sector and creates island of calculational and allocational chaos, because inside these islands, the absence of the prices of the means of production render impossible the execution of economic calculation ${ }^{109}$.

Since 1995, the lack of an information structure rendered impossible or highly distorted the associated economic calculation; this in turn facilitated entrepreneurial errors, that eventually developed in clusters ${ }^{110}$ of malinvestment starting 1995.

108 «El ejercicio sistemático de la coacción y la manipulación de los indicadores del mercado, resultado de la intervención gubernamental o de la concesión de privilegios por parte del gobierno a grupos de interés (sindicatos, bancos, etc.), impiden que se cree y descubra la información necesaria para coordinar la sociedad, generándose de manera sistemática graves desajustes y descoordinaciones sociales». Huerta de Soto, 2002, p. 280, nota 66.

109 «...two or more stages could not be totally integrated vertically on the marketfor total integration would eliminate a whole segment of the market and establish an island of calculational and allocational chaos, an island that would preclude optimal planning for profits and maximum satisfaction for the consumers. In the case of simple government ownership, still another extension of this thesis becomes evident. For each governmental firm introduces its own island of chaos into the economy; there is no need to wait for full socialism for chaos to begin its work. No government enterprise can ever determine prices or costs or allocate factors or funds in a rational, welfare-maximizing manner. No government enterprise could be established on a «business basis» even if the desire were present. Thus, any governmental operation injects a point of chaos into the economy; and since all markets are interconnected in the economy, every governmental activity disrupts and distorts pricing, the allocation of factors, consumption/investment ratios, etc. Every government enterprise not only lowers the social utilities of the consumers by forcing the allocation of funds to other ends than those desired by the public; it lowers the utility of everyone (including the utilities of some government officials) by distorting the market and spreading calculational chaos. The greater the extent of government ownership, of course, the more powerful will this impact become.» Rothbard, 1993, p. 825 (Underlined mine).

110 On this subject the works of Hulsmann and Kirzner are strongly suggested. 
For completeness it is useful to remark that the markets associated to the Internet in those years were subject to a second cause of distortion, due to the inflationary monetary and credit policies adopted by the Federal Reserve that led, five years later to the pop of the Internet Bubble ${ }^{111}$.

III.

\section{CONCLUSIONS}

The most remarkable events of the History of the Internet have been highlighted, from its birth to 1995, the year of effective commercialization. This period is spread with continuous signs of government intervention that introduced distortions in the market process involved in the conception and development of the Internet.

At the time of the birth of the Internet, many institutional restrictions were in place. At the same time science and society were ready to explore the concept of a computing network. Only the US Federal Government, allowing itself a freedom not permitted to actors of the private sector, was able to set the first milestone: ARPANET

Furthermore, the prohibition to provide commercial services over the public Internet originated severe distortions; among them, the failure to allow a spontaneous formation of a knowledge structure for the Internet sector. The success of other industries (mainly the microprocessors' one) exerted such a pressure that obligated the US Government to pass the control over the private sector. The transition was finalized with the Privatization and Commercialization Act, effective by 1995.

Our economic analysis has been focused on two points. First, the government failure in maintaining a service that had been public funded precisely under the justification of the market

111 Starting 1995 the United States were victims of a violent monetary expansion policy that put in motion an Austrian economic cycle. The cycle adds a further layer of distortion to the development of the productive structure associated to the Internet. For an analysis of the application of the Austrian Business Cycle to the Internet Bubble, see Neri, 2004. 
failure to provide such a service. Second, the absence of a knowledge structure in the Internet sector, once the commercialization was completed, represented the fertile soil over which entrepreneurial errors sprouted from. These errors were the sparkle that probably generated the first malinvestments during the period of the Internet Bubble.

\section{BIBLIOGRAPHY}

Armentano, D. (1999), Antitrust: The Case for Repeal, Ludwig von Mises Institute, p.28

BickerstafF, S. (1999), «Shackles on the Giant: How the Federal Government Created Microsoft, Personal Computers, and the Internet», Texas Law Review, Volume 78, Number 1.

CAssidy, J. (2002), Dot.con: The Greatest Story Ever Told, HarperCollins Publishers; 1st edition.

Colombatto, E. (2000), «Is There an Austrian Approach to Transition?», ICER.

CooK, G. (1992), «NSFnet «Privatization» and the Public Interest: Can Misguided Policy be Corrected?», The Cook Report, 1992, http://www.cookreport.com/p.index.shtml

FisHeR, S. (1991), «Whither NREN?», Byte, July http:/ / www.byte. com/art/9607/sec4/art1.htm\#076bl1c2

Friedman, M. (1953), «The Methodology of Positive Economics», in Essays in Positive Economics, University of Chicago Press.

FrischmanN, B. (2001), Privatization and Commercialization of the Internet Infrastructure: Rethinking Market Intervention into Government and Government Intervention into the Market, 2 COLUM. SCI. \& TECH. L. REV. 1 (June 8) http:/ / www.stlr. org $/$ cite.cgi? volume $=2 \&$ article $=1$.

GeIst, M. A., The Reality of Bytes: Regulating Economic Activity in the Age of the Internet, (http:/ / web.archive.org/web/ 20020319043328/http:/ /www.law.washington.edu/wlr/ GEIST.HTM).

HAFNER, K. y M. Lyon (1996), Where the wizards stay up late, Touchstone, New York. 
Hennings, K. (2001), La teoria austriaca del valor, el capital y el interés, Ediciones Aosta.

Huerta De Soto, J. (1986), «Método y crisis en la ciencia económica», in Lecturas de Economía Política, Vol I, Unión Editorial.

Huerta de Soto, J. (1992), Socialismo, Cálculo Económico y Función Empresarial, Unión Editorial, Madrid. (3 ${ }^{\text {rd }}$ edition 2005).

Huerta de Soto, J. (2002), Dinero, Crédito Bancario y Ciclos Económicos, $2^{\text {nd }}$ Ed., Unión Editorial, Madrid. (3rd edition 2006).

INFANTINO, L (2003), Ignorance and Liberty, Routledge.

InFANTINO, L. y N. Iannello (2004), Ludwig von Mises: le scienze sociali nella Grande Vienna, Rubettino.

Information Infrastructure Executive Order 9/15/93,: http://www. interesting-people.org/archives/interesting-people/ 199309/msg00076.html.

IRvine, M., DRAKE, W. y DowDy, E. (1999), Internet Industry History, http://cct.georgetown.edu/curriculum/505-99/internet3.html.

LARRIBEAU, R. Jr. (1993), «Internet Providers: The Future for the Commercial Internet Service Providers», The Internet Business Journal, Volume 1, Number 2 - August, http:/ / lists. village.virginia.edu/lists_archive/Humanist/v07/0233.html. Leiner, B.M., Vinton, G.C. , Clark, D.D., Robert, E.K., Kleinrock, L., Lynch, D.C., Postel, J., Roberts, L.G., WolfF, S. (2003), A Brief History of the Internet, The Internet Society, (http://www.isoc. org/internet/history/brief.shtml).

MacKie-Mason, J.K., Varian, H.R. (1993), «Some Economics of the Internet», (1992), paper prepared for the Tenth Michigan Public Utility Conference at Western Michigan University March 25-27.

Menger, C. (1994), Principles of Economics, Libertarian Press.

Mises, L. von (1963), Human Action, third revised edition, Fox and Wilkes, San Francisco.

Massimiliano, N. (2004), "Applicazione della teoria austriaca del ciclo economico all'Internet Bubble», in Infantino y N.Iannello, Ludwig von Mises: le scienze sociali nella Grande Vienna, Rubettino Editore.

Network Working Group (1990), Commercialization of the Internet, Summary Report, Harvard, November, http:/ / www.cse. ohio-state.edu/cgi-bin/rfc/rfc1192.html. 
Noll, R., Owen, B., «Anticompetitive Uses of regulation: United States vs. AT\&T (1982)», in J. Kwoka and L. White, The Antitrust Revolution (http://www3.oup-usa.org/sc/ 0195161181/pdf/0673468801_12.pdf).

Office of Inspector General of the National Science Foundation (1993), OIG Review of NSFNET, April 23, http: / / www.nsf. gov/pubs/stis1993/oig9301/oig9301.txt.

Quarterman, J. S., Smoot, C.M. (1994), The Internet Connection, Addison Wesley.

Rothbard, M. (1973), For a New Liberty, Collier Books, London. Rothbard, M. (1993), Man, Economy, and State, The Ludwig von Mises Institute.

Stiglitz, J. (2004), The Roaring Nineties, W. W. Norton \& Company. Thomson, J. Jr. (2000), Privatization of the New Communication Channel: Computer Networks and the Internet, http:/ / www. sit.wisc.edu/\%7Ejcthomsonjr/j561/NSFpolicy-7.html

U.S. Department of Defense (1968), Request for Quotation, http: / / www.cs.utexas.edu/users/chris/DIGITAL_ARCHIVE/ ARPANET/RFQ-ARPA-IMP.pdf.

Zakon, R. H, Hobbes' Internet Timeline, http:/ / www.zakon.org/ robert/internet/timeline/ - 1980s. 